\title{
LATVIAN TEACHERS ON PRIMARY SCHOOL PUPILS' SOCIAL SUSTAINABILITY
}

\author{
Elga Drelinga
}

Sandra Zarina

Dzintra Iliško

Daugavils University, Latvia

\begin{abstract}
The aim of the study is to explore teachers' view about a social responsibility of primary school teachers and pupils' social sustainability as viewed by the teachers. Social sustainability defines responsible and wise decision making at present as a significant precondition for development of a sustainability-oriented society in the future, the bases of which is an efficient individual's, society's and environments' interchange. Personal and a social competence is a significant component of social sustainability that fosters possibilities of each pupil's individual development and interrelatedness, by providing solutions to the problems that arise in the pedagogical process. Research methodology used for the purpose of the study are focus group interviews $(n=45)$ that involve 234 teachers from all over Latvia. Research results indicate that teachers while expressing their opinion about the contemporary primary school children create a profile of their social sustainability. Among the most significant features of a profile of contemporary pupils, the teachers have mentioned such pupils' values which are not acceptable for them. This indicates that teachers cannot trust and accept children's role as equal partners in the learning process. This situation may create problems in reorienting education towards a competency-based learning process. Therefore, the authors have analyzed the opportunities for the teachers' professional development by paying a deeper attention to an intergenerational relation in the context of social sustainability.
\end{abstract}

Keywords: primary school children, social sustainability, social and personal competency, teachers

\section{Introduction}

Teachers, parents, children and the society set the aim for the learning process. The way this aim is set depends the future of a child and the society. For the children to become active participants in the society, this is essential to view educational system through the sustainability lens. Therefore, there is a necessity to explore the situation in school and, if necessary, to make changes, to look for the solutions in order to develop a learning environment based on a respect of the needs of children. Noddings (1998) has emphasized that one need to change one's understands about changes, which involve not only a desire to transform education but to reformulate the aim of education based in systemic and sustainable paradigm (Salite, 2006). 
Table 1. The components of Social and Personal Competency

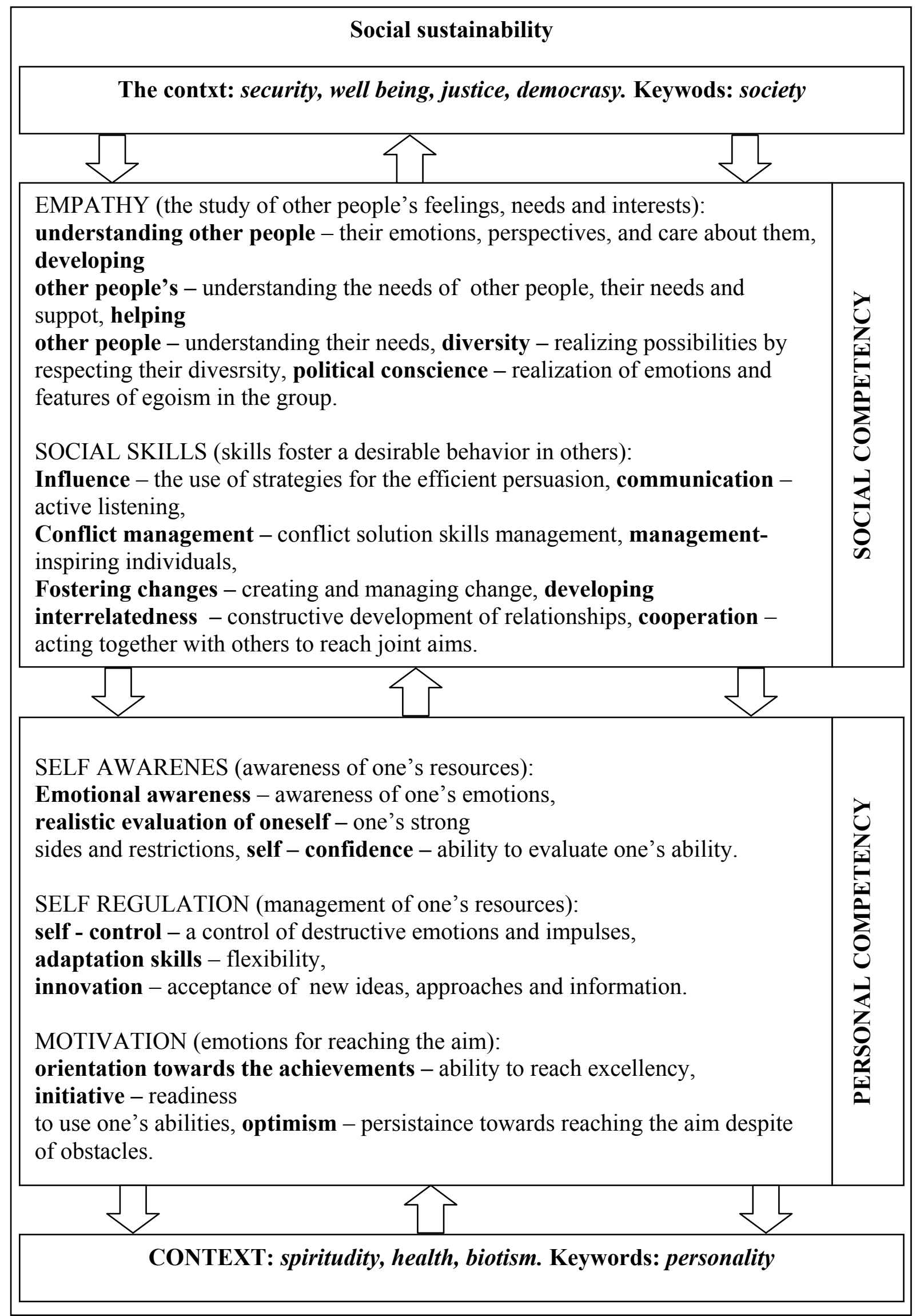


The analyses of a local and international literature as well as the latest research in the field of social and emotional competency indicates that one of the problems which is not widely discussed in the literature is learning today with the thought about tomorrow (Hicks, 2010). The processes that are taking place in the society and education cannot be viewed as linear any longer but rather as circular (Posch, Steiner 2006; Webster, Johnson 2010; Iliško, Ignatjeva, \& Mičule, 2010). Majority of scientists discuss about the possibilities to design a sustainable learning environment in the educational process (Brundiers, Wiek, Redman 2010; British Department of Education and Skills 2007; Grabovska, 2010, Badjanova, Iliško, \& Drelinga, 2013; Drelinga \& Krastina, 2012). They stress the need for the new solutions how to ensure sustainable development of the society and economy. Innovations are the most required in the situations where the standard situations do not work any longer and one needs to apply creative solutions. Thoresen (2004) has emphasized the need for the individual's sustainability that involves individual's responsibility: communicative ability and problem solving skills. The main way leads children to become responsible citizens who help to reach towards global sustainability. Particular emphases should be paid to a personal competency (Miller, 1995). Grabovska (2006) indicates that a social aspect of sustainability is closely related to one's health, biotism, spirituality, and a personal competency. It has to do with some societal aspects such as a well-being, justice, rights and a social competency (see Table 1.).

The table below presents a summary of the main components of pupils' social and personal competency as based on literature review and the data gained from the empirical study.

This table reflects the main components of pupil's social and personal competency that will be described in a detailed and analytic way illustrated with the data gained from this study.

\section{Research methodology}

Research participants were $1^{\text {st }}-6^{\text {th }}$ grade teachers $(n=234)$. The main research method used was focus group interviews $(n=45)$, each group comprising 4 - 6 participants. The main issue of a discussion was a profile of a contemporary pupil. Each research participant has shared his/her opinion about a contemporary pupil and their needs and characteristics. At the beginning each participant was asked to make a picture of how does contemporary pupils look like, then, in joint discussions shared their views about pupils' values, characteristics and problems they encounter. The focus groups are designed to learn participants' opinion on certain issues. The participants' responses are shaped by the specifics of their cultural background and mentors' experience (Munday, 2006). In contrast to an individual interviews, (Jupp, 2006; Pipere, 2011) focus group interviews allow to gain data and opinions by interacting 
among the participants of the group. The peculiarity of this method is that each participant gains a pleasant and creative experience in joint discussion.

Data gathering took place in a relatively short time frame and with few resources used. The participants explored and formulated their ideas related to the issues of a discussion; they formulated their priorities and perspectives. Formulations of the issue offered by the participants indicated to the interrelatedness among the participants and a moderator (Alasuutari, Bickman, Brannen, 2008). Focus groups are taking place with the aim to get the information about the issues that are defined by the moderator (Hughes \& Dumont, 1993; David, Stewart \& Prem, 2007; Shamdasani, Dennis \& Rook, 2007).

The issues are explored from the point of view of participants and are shaped by the moderators' experience (Munday, 2006). The advantages of the use of a focus group interview includes: discussion of an issue in a group, formulation of priorities and diverse perspectives. The content analyses method was used with the purpose of learning participants' ideas, understandings, and opinion about the issues of the study (Pipere, 2011). During the whole research process researchers have ensured the anonymity of participants. According to Kolb (2008), this is an excellent method to generate new ideas and look for the solutions of the problem.

Several authors (Barbour \& Kitzinger 1999; Miller \& Brewer, 2003; Jupp, 2006) have mentioned that the results gained from the focus group interviews can be used to test ideas and to understand the choices which the participants have made about a certain issue.

\section{The opinion of primary school teachers: the analyses of data}

The research participants were chosen according an accident selection principle. They represent diverse schools of Latvia. The qualitative research method used in this study was focus group interviews where a groups of participants discus certain issues (Pipere, 2011:177), with the defined theme by the moderator of a discussion (Hughes \& Dumont 1993, Clavin \& Lewis, 2005; Stewart, Shamdasani \& Rook, 2007), and by selecting certain number of questions (Krueger \& Casey, 2000; Jupp, 2006; Alasuutari, Bickman, Brannen, 2008).

\section{The perspective of the $1 \mathrm{st}-4$ th grade teachers about their pupils}

All opinions expressed by the teachers can be viewed and analyzed through the social sustainability lens where the main categories that were singled out in focus group interviews are security, well-being, justice, democracy, biotism, health, and spirituality.

The focus group interviews helped to identify the following categories: security, well - being, justice, and pupils' rights. 
Security is closely related with the order and stability that needs to be noticed and observed. Pupils learn best when they feel secure and evaluated. They feel free to choose the theme, to make mistakes and to overcome difficulties in the learning process. Parental support is essentially important for the primary school children.

The second most pronounced category was a well - being and justice.

Teachers consider that many of their pupils are "poor" that indicates to the signs of social segregation. "Social segregation” and justice influence pupils" life in the school community. "Social inequality" is one of the issues at school, and pupils have a tendency to discuss the status of pupils in the classroom.

Almost all teachers have stressed the problem about „Children knowing their rights, and the ignorance of their duties" (3 groups). Teachers emphasize their responsibility to teach children their rights and to evaluate their behavior and duties.

On the one side children have knowledge that foster biotism, a wise use of resources. On the other side, the teachers have emphasized the unwillingness of children "to view nature even through the window," and point to children's "lack of a deeper knowledge about the surrounding environment," as well as "having narrow interests" that reduces biotism.

On the other side, contemporary pupil is described as "restless"(14) that implies the movement without the aim, though children are "physically active".

Health was also among the most frequently mentioned categories. Teachers pay most of the attention to the tendencies when the situation makes one to be worried. Each year teachers encounter significant health issues by naming them as "health problems" (9), "lack of strong health of pupils, (3)" and "a nervousness" among pupils (2). They related these consequences to the ecological issues, "lack of exercising" (8) among pupils, the use of a car as a means of transportation by parents by bringing their kids to school" (2), and the "exclusion" of a child (8) in the family. Among the unhealthy habits they have mentioned the use of junk food, such as "chips", "chupa - chups," rather than vegetables.

The next category that was mentioned by the teachers was spirituality. Pupils pay more significance to material values (5). Pupils are interested about "becoming rich and famous." (5) "Their ideals are singers which are not known by the teachers" (3). Teachers did talk about the negative influence of TV, internet, and technologies. Among the other objects of attraction for pupils as mentioned by the teachers, are cartoons, music, vampire movies, entertainment, exotic travels, and iphones. To describe the attributes of contemporary pupils, the teachers have used such vocabulary as a free way of dressing and fashionable clothing. Teachers did acknowledge that a majority of pupils are "envious" (5), and that they have no skills of cultural behavior. They emphasize that pupils are helpful (3), ,share things", they care about their families. Among 
them there are pupils who are being ,ridiculed, ignored, who are cruel, who are being humiliated (2)."

Personal competency. Contemporary pupils learn how to express their feelings, they are "easily hurt", "emotionally imbalanced" (7), though they are very „kind” (4), „friendly," (3) learn how to manage their anger: they are ,angry” (4), ,aggressive” (5), they like, "aggressive games”. More often they do not have a realistic self-evaluation of their advantages and disadvantages. More often pupils are "egoistic" (2), they place more emphases on one's "ME", "only me", "self-centeredness," they have a high self-evaluation, and they are not self - critical.

Contemporary pupils are self-confident; they have realistic understanding of their abilities. Teachers pay attention to their overly high self-evaluation (3), ability to do diverse things. They demand from the surrounding people "attention to themselves", "they love themselves." They control destructive emotions; they are impulsive and "attractive" (2). Quite often they have "a destructive behavior," "they do not control their behavior," they are described as "hyperactive" and as "indigo" children.

Credibility - honesty and integrity. Pupils need to find and to evaluate possible solution of the problem, to choose a problem solution strategy, to evaluate a result, so that the choice is justified. Teachers expressed diverse opinions about pupils' ability to undertake a responsibility about their personal achievements. Some teachers have emphasized that pupils can undertake a responsibility about personal achievements. Other teachers stressed that pupils are "irresponsible" (3) and "do not want to undertake a responsibility" (5)" that they lack a responsibility. Pupils are flexible and stubborn. Children are creative, they are quick decision makers, each has its own experience. Still several children are ignorant, learning creates problems for them. They are "knowledgeable in use of technologies," they "know how to work with IT4"

On the one side they "get used to be independent" (2). Parents, teachers and the society motivate them for a "career, and learning". "Each primary school pupil has a "desire to be the first and the best" (2), "they have a high motivation for learning" (4) and an orientation for the achievements. On the other side, children "lack independence" (3). Children do not think about learning and their motivation for learning is low.

Primary school children have difficulties to set long term goals. Contemporary children "are open to new things" "they have many questions" (3) they are "curious" (4). This fosters children's learning. In many issues children are "knowledgeable" (10), and "informed" (2). "Memory," "attention," and a "perception" help them to learn new things quickly and profoundly. They "think in a creative way," analytically, with imagination, they are "gifted and clever" (3). In the classroom children "feel safe," (15), in the classroom, they are "active" (14), "ready for work" (3).This is acknowledged that the development of opportunities can be delayed because „pupils read books less" (3), ,they have 
no desire to read" (3). This leads to „poor vocabulary". The child is "lazy" (4), he/she waits until somebody does his/her work". Pupils are described with "a poorly developed muscular system, problems with memory, and with speech problems."

Social competence determines one's actions in relation to others and has its expression as: (1) are cognition of other people's need and feelings. Social skills (2) are defined as an ability to foster a desirable behavior. Therefore, person begins to understand others, if necessary, to provide help and support others.

One of the significant social skills as described by the teachers is influencing others. From one side, teachers describe pupils as "talkative subjects" by putting the emphases on a "vocabulary pupils are using". Pupils learn to persuade and influence peers and adults. Some teachers stress that children are not "talkative subjects" but are simply laud.

The requirements set for the primary school teachers are not only to teach pupils to be responsible but to learn the communication management skills in the group. Contemporary children "like to teach, each wants to be the center (3)." The teacher is strict, learns to establish order and to encourage others to understand them.

\section{Discussion}

This does not takes place quite often when teachers pose a question how does the pupil look like, what is his/her values, attitude towards life, which skills he or she needs to acquire to become a citizen of a future society.

A portrait of a contemporary pupils centers around pupils' needs for a security both in the family and in the classroom, social inclusion, being included in the classroom activities, being provided a space of an exploration of the world. Contemporary pupil is self-confident, overly engaged with IT technologies, spends less time in nature, is consumerist minded, and encounters health problems from being distant from nature and from spending more time with technologies.

The authors believe that building social skills and competency is essential for the pupils to become responsible citizens, since the social and emotional growth of a student precedes all other growth. Social intelligence plays an integral role how the transition takes place into next stage of development. Without a social intelligence pupils may encounter difficulties of participating in a community life. Low social skills may be linked to a number of problems, like drop outs, and poor socialization.

The data gained in this research, based on focus group interview with teachers indicate that teachers are ready to face diversity in the classroom, though; the main means of communication among pupils is via IT technologies more than by a direct contact. Pupils spent too much time with the technologies, less with peers. 
The moderators of a focus group discussions have noticed that teachers do not understand that for a contemporary pupil traditional learning style is not acceptable any more where the knowledge transmission takes place in a linear way. The teacher needs to help children to find, to evaluate, and to use necessary knowledge and put it in practice. Interrelatedness in the learning process is based upon respect and trust that can cause an antipathy towards the school.

\section{References}

Alasuutari, P., Bickman, L., \& Brannen, J. (2008). The SAGE Handbook of Social Research Methods 21.Focus Groups. London: Sage Publications.

Badjanova, J., Dz., Ilisko, \& E., Drelinga. (2013). Holistic Approach in Reorienting Teacher Education Towards the Aim of Sustainable Education: the Case Study from the Regional University in Latvia. Procedia - Social and Behavioral Sciences, ISSN: 18770428 .

Barbour, R.S., \& Kitzinger, J. (1999). Developing Focus Group Research Introduction: the Challenge and Promise of Focus Groups. In: Barbour, R. S., Kitzinger, J. Developing Focus Group Research. London: Sage Publications. (pp. 1-20). http://srmo.sagepub.com/view/developing-focus-group-research/n1.xml [2011.05.02].

Brooks, G. \& Brooks, M. (1999). Search of Understanding: The case for Constructivist Classrooms. Alexandria, VA: Association for Supervision and Curriculum Development.

Brundiers, K., Wiek, A., \& Redman, C.L. (2010). Real-World Learning Opportunities in Sustainability: From Classroom into the Real World. In: International Journal of Sustainability in Higher Education, 11, (4). (pp. 308-324). http://www.emeraldinsight.com/1467-6370.htm [2010.12.20].

Clavin, B. \& Lewis, A. (2005). Focus Groups on Consumers': Ethical Beliefs. In: Harrison, R., Newholm, T. \& Shaw, D. (2005) The Ethical Consumer. London: Sage Publications. $173-187$.

David, W. Stewart \& Prem, N., (2007). Focus Groups: History, Theory, and Practice: Sage Publications.

Department of Education and Skills (2007). Sustainable Development: Our Commitment. www.dfes.gov.uk/aboutus/sd/ [2007.06.12].

Drelinga, E., \& Krastina, E. (2012). Assessment of Primary School Learner's Project Week in the Context of Sustainable Development. In: С. Жалован, Proceedings of International Scientific Conference Current Trends in the Concepts and Strategies of Lifelong Learning, Сант-Петербург, Россия, ISBN978-57434-0614-5.

Grabovska, R. (2006). Ilgtspējības principa ìstenošana skolotāju izglītībāa. [Implementation of the Principle of Sustainability in Teacher Education] Phd Thesis. Daugavpils: Daugavpils University.

Grabovska, R. (2011). Mācību Process Ilgtspējīgai Ekonomikai un Sabiedrībai: Gadījumai Izpēte Latvijas Kontekstā. [Study process for sustainable economic and society: Latvian case study] Daugavpils Universitātes 53.Starptautiskās zinātniskās konferences materiāli 2011.gada 13.-15.aprīlis. Daugavpils, Downloaded from http://dukonference.lv/public/proceedings_of_conf/53konf/pedagogija/Grabovska.pdf

Hicks, D. (2010). The Long Transition: Educating for Optimism and Hope in Troubled Times. 3rd Annual Conference of the UK Teacher Education Network for Education for Sustainable Development/ Global Citizenship, July 2010 1-28.

Hughes, D., DuMont, K. (1993). Using Focus Groups to Facilitate Culturally Anchored Research. American Journal of Community Psychology, 21 (6): 775 - 806. 
Iliško, Dz., Ignatjeva, S., \& Mičule, I. (2010). Teachers as Researchers: Bringing Teachers' Voice to the Educational Landscape. Journal of Teacher Education for Sustainability, 12 (1), 51-65 (ISSN 1691-4147). DOI: 10.2478/v10099-009-0046-x

Jupp, V. (Ed.) (2006). The SAGE Dictionary of Social Research Methods. London: Sage Publications. (pp.122-123). Downloaded from: http://srmo.sagepub.com/view/the-sageencyclopediaof-social-science-research-methods/n82.xml?rskey=5OWXn6 [2011.04.30].

Kolb, B. (2008) Marketing Research: 8 Planning and Conducting Focus Groups. SAGE Research Methods Online. Sage Publications, Inc. 124-140 DOI: 10.4135/9780857028013

Krueger, R., Casey, M. (2000). Focus Groups: A Practical Guide for Applied Research. (3 ${ }^{\text {rd }}$ edition) Newbury Park, CA: Sage Publications.

Miller, R. (1995). Educational Freedom for a Democratic Society: A Critique of National Goals, Standards, and Curriculum. Brandon, VT: Resource Center for Redesigning Education.

Miller, R.L., \& Brewer, J. (Ed.). (2003). The A-Z of Social Research. London: Sage Publications. (pp. 121-123). Downloaded from http://srmo.sagepub.com/view/the-a-zof-socialresearch/n41.xml?rskey=5OWXn6.

Munday, J. (2006). Identity in Focus: The use of Focus Groups to Study the Construction of Collective Identity. Sociology, 40,1, 89-105.

Noddings, N. (1998). Philosophy of Education. Colorado: Westview Press.

O'Sullivan, E. (1999). Transformative learning: Educational vision for the 21st century. London, New York: Zed Books, In Association with University of Toronto Press, Toronto.

Pipere, A. (2011). Fokus grupas [Focus groups] In: Martinsone, K. (Ed.) (2011). Ievads pētniecībā: Stratēégijas, Dizaini, Metodes. (pp.177-181) [Introduction in research: strategy, design and methodology] Rīga: Raka.

Posch, A., \& Steiner, G. (2006). Integrating Research and Teaching on Innovation for Sustainable Development. International Journal of Sustainability in Higher Education, 7(3), 276-292, Downloaded from http://www.emeraldinsight.com/1467-6370.htm.

Salite, I. (2002). Teachers' Views on the Aim of Education for Sustainable Development. Journal of Teacher Education and Training, 1, 68-80.

Salite, I. (2006). Aim of Education in the Context of Present and Future Educational Issues: Perspective of Teachers. In: A. Pipere (Ed.). Education \& Sustainable Development: First Steps toward Changes, 1, (pp. 390 - 407). Daugavpils: Daugavpils University Publishing House "Saule".

Salīte, I. (2008). Educational Action Research for Sustainability: Constructing a Vision for the Future in Teacher Education. Journal of Teacher Education for Sustainability, 10, $5-16$.

Thoresen, V. (2004). Cultivating Sustainable Lifestyles. UNESCO: IEF Conference, Greece: University of Thessaloniki.

UN ESD (2004). DESD Draft International Implementation Scheme. Paris: UNESCO

Webster, K, \& Johnson, C. (2010). Sense \& Sustainability.Educating for a Circular Economics. UK: Ellen MacArthur Foundation. 